\title{
Znakowanie żywności jako instrument realizacji celów prawa żywnościowego - wybrane problemy
}

\section{Wstęp}

Jedną z istotnych części prawa żywnościowego są akty prawne regulujące kwestię przekazywania konsumentom informacji na temat żywności, a w szczególności znakowania żywności. Zakres tych regulacji jest z jednej strony bardzo obszerny, a z drugiej - niezwykle szczegółowy. Zainteresowanie prawodawcy znakowaniem żywności wynika $\mathrm{z}$ funkcji, jakie wiążą się ze znakowaniem środków spożywczych. Informacje zawarte na etykiecie środka spożywczego stanowią w zasadzie podstawowy sposób komunikacji między producentem a konsumentem na zglobalizowanym rynku, gdzie producent zwykle nie ma bezpośredniego kontaktu z konsumentem, a zatem nie może mu w inny sposób przekazać koniecznych informacji o swoim produkcie. Sprzedawca natomiast często nie posiada oczekiwanej przez konsumentów wystarczającej wiedzy na temat produktów, którymi handluje. W sytuacji, gdy konsument nie ma bezpośredniego kontaktu z producentem, a w obrocie znajdują się tysiące produktów spożywczych, etykieta towarzysząca konkretnemu produktowi pozwala konsumentowi zapoznać się z nim, porównać go z innymi produktami i dokonać świadomego wyboru przy zakupie ${ }^{1}$. Etykieta pełni więc przede wszystkim funkcję czysto informacyjną.

* Uniwersytet Warszawski.

${ }^{1} \mathrm{P}$. Wojciechowski, Regulacje dotyczace informacji na temat żywności, w: M. Korzycka, P. Wojciechowski, System prawa żywnościowego, Warszawa 2017, s. 416. 
Z badań konsumenckich wynika, że informacje zawarte na opakowaniach produktów są jednym z głównych źródeł informacji o produktach żywnościowych, co świadczy o tym, że mają duże znaczenie podczas podejmowania decyzji o zakupie ${ }^{2}$. Konsumenci zwracają uwagę na informacje przede wszystkim wtedy, gdy pierwszy raz kupują określony produkt lub gdy dokonują porównania dwóch produktów z tej samej kategorii ${ }^{3}$. Producenci dążący do wzmacniania swojej pozycji rynkowej poprzez dobór treści i formy informacji zamieszczanych na etykietach (odnoszących się nie tylko do cech danego produktu, ale także odwołujących się do emocji i odczuć konsumentów) wpływają zatem na wybory konsumenckie. Biorąc pod uwagę konkurencję rynkową, etykieta pełni więc także funkcję marketingową (promocyjną, wyróżniającą). Poprzez zamieszczenie określonych informacji, a czasem nawet sam sposób jej formułowania, producent dąży do wyróżnienia swojego produktu.

Jednocześnie ta szczególna funkcja etykiety, jaką jest kształtowanie czy wpływanie na zachowania konsumenckie, może być i jest wykorzystywana do realizacji interesu publicznego. Zamieszczając określonego rodzaju informację, można bowiem wpływać na zmianę zachowań konsumentów w sposób zaplanowany, nakierowany na realizację konkretnych celów publicznych.

${ }^{2}$ M. Olejniczak, Zróżnicowanie źródet informacji konsumenckiej o żywności prozdrowotne, „Handel Wewnętrzny” 2017, nr 6(371), s. 259; L. Nieżurawski, C. Sobków, Rola informacji na etykiecie w procesie zakupu produktu żywnościowego, ,Roczniki Naukowe Stowarzyszenia Ekonomistów Rolnictwa i Agrobiznesu" 2015, t. XVII, nr 3, s. 290; I. Ozimek, M. Tomaszewska-Pielacha, Czynniki wplywajace na czytanie przez konsumentów informacji zamieszczanych na opakowaniach produktów żywnościowych, „Studia i Materiały Polskiego Stowarzyszenia Zarządzania Wiedzą" 2011, nr 52, s. 26 i 28; I. Ozimek, M. Tomaszewska, Znaczenie wybranych źródet informacji o produktach żywnościowych dla konsumentów, „Handel Wewnętrzny” 2011, nr 2, s. 49 i 51. Autorki opierały się zarówno na własnych badaniach empirycznych, jak i na wynikach badań przeprowadzonych w 2009 r. przez International Food Information Council (IFIC) na populacji amerykańskiej. Analogiczne wyniki uzyskano także w innych badaniach, zob. I. Ozimek, Znaczenie wybranych źródet informacji o żywności dla konsumentów, w: K. Gutkowska, I. Ozimek (red.), Konsument żywności i jego zachowania rynkowe, Warszawa 2000, s. 536-541; K. Żelazna, H. Górska-Warsewicz, Źródta informacji wykorzystywane przy zakupie żywności, w: J. Karwowski (red.), Polski konsument i przedsiębiorstwo na jednolitym europejskim rynku, Szczecin 2005, s. 79-85; K. Staniewska, H. Panfil-Kuncewicz, B. Staniewski, M. Mieczkowska, Postrzeganie informacji żywieniowej przekazywanej za pomoca różnych form przekazów komercyjnych, ,Zeszyty Naukowe SGGW. Ekonomika i Organizacja Gospodarki Żywnościowej” 2010, nr 86, s. 118.

${ }^{3}$ I. Ozimek, M. Tomaszewska-Pielacha, Czynniki wptywające na czytanie..., s. 30. 
Należy przy tym podkreślić, że generalną zasadą prawa żywnościowego jest zapewnienie konsumentom podstawy do dokonywania świadomych wyborów dotyczących spożywanej przez nich żywności i uniemożliwienie jakichkolwiek praktyk, które mogłyby wprowadzić konsumentów w błąd ${ }^{4}$. Ujmując to od strony konsumentów, można stwierdzić, że mają oni prawo do informacji na temat spożywanej przez nich żywności ${ }^{5}$. W celu realizacji powyższej zasady w prawie unijnym została określona i szczegółowo uregulowana lista informacji obowiązkowych, które muszą być zamieszczone na etykiecie, a ponadto dopuszczona została możliwość zamieszczenia dodatkowych informacji, określanych jako informacje dobrowolne. Zarówno zatem funkcja informacyjna, promocyjna, jak i funkcja nakierowana na osiaganie celów publicznych muszą być realizowane w granicach tego podstawowego założenia.

Niniejszy artykuł obejmuje analizę regulacji unijnych dotyczących znakowania żywności pod kątem nakierowania ich na realizację poszczególnych celów prawa żywnościowego wyrażonych wprost w rozporządzeniu 178/2002, takich jak: zapewnienie wysokiego poziomu ochrony życia i zdrowia ludzkiego, ochrona interesów ekonomicznych konsumenta, zagwarantowanie rzetelności transakcji handlowych, ochrona zdrowia i warunków życia zwierząt oraz ochrona środowiska naturalnego człowieka, ze względu na ścisłe powiązanie z produkcją, przetwarzaniem i dystrybucją żywności ${ }^{6}$.

Zadaniem artykułu jest ustalenie, w jaki sposób cele prawa żywnościowego są realizowane przez przyjętą regulację dotyczącą znakowania żywności, oraz zbadanie, czy realizacja poszczególnych celów nie zagraża realizacji pozostałych.

${ }^{4}$ Art. 8 ust. 1 rozporządzenia Parlamentu Europejskiego i Rady (WE) nr 178/2002 z 28 stycznia 2002 r. ustanawiającego ogólne zasady i wymagania prawa żywnościowego, powołującego Europejski Urząd ds. Bezpieczeństwa Żywności oraz ustalającego procedury w sprawie bezpieczeństwa żywności (Dz. Urz. UE L 31 z 1.02.2002 r., s. 1 ze zm.) (dalej: rozporządzenie 178/2002), pkt 4 preambuły oraz art. 3 ust. 1 rozporządzenia Parlamentu Europejskiego i Rady (UE) nr 1169/2011 z 25 października $2011 \mathrm{r}$. w sprawie przekazywania konsumentom informacji na temat żywności, zmiany rozporządzeń Parlamentu Europejskiego i Rady (WE) nr 1924/2006 i (WE) nr 1925/2006 oraz uchylenia dyrektywy Komisji 87/250/EWG, dyrektywy Rady 90/496/EWG, dyrektywy Komisji 1999/10/ WE, dyrektywy 2000/13/WE Parlamentu Europejskiego i Rady, dyrektyw Komisji 2002/67/ WE i 2008/5/WE oraz rozporządzenia Komisji (WE) nr 608/2004 (Dz. Urz. UE z 22.11.2011 r., s. 18 ze zm.) (dalej: rozporządzenie 1169/2011).

${ }_{5}^{5}$ Pkt 3 preambuły oraz art. 1 ust. 2 rozporządzenia 1169/2011.

${ }^{6}$ Poza zakresem rozważań pozostaje natomiast cel w postaci zapewnienia swobodnego przepływu żywności na jednolitym rynku, co wynika z tego, że realizacja pozostałych celów poprzez regulacje dotyczące znakowania w istocie wpływa na zapewnienie swobodnego przepływu towarów. 


\section{Zapewnienie wysokiego poziomu ochrony życia i zdrowia ludzkiego}

Zapewnienie wysokiego poziomu ochrony zdrowia i życia ludzi stanowi niewątpliwie najważniejszy cel obowiązującego prawa żywnościowego ${ }^{7}$. Ta szczególna pozycja ochrony życia i zdrowia ludzkiego wynika przede wszystkim z charakteru dóbr chronionych tym celem - życie i zdrowie są wartościami o największym znaczeniu - oraz znajduje potwierdzenie zarówno w przepisach Traktatu o funkcjonowaniu Unii Europejskiej (TFUE) (głównie art. 9, art. 168, ale także art. 169 ust. 1 i art. 191 ust. 1 tiret 2), jak i bezpośrednio w treści aktów prawnych z zakresu prawa żywnościowego. Z treści rozporządzenia 178/2002 wynika, że ochrona zdrowia i życia człowieka traktowana jest w prawie żywnościowym jako cel pierwszorzędny i nadrzędny, gdyż jedynie w odniesieniu do zdrowia i życia mowa jest o ,wysokim poziomie ochrony”, a nie o „ochronie” jak w przypadku pozostałych celów prawa żywnościowego.

Należy podkreślić, że także w rozporządzeniu 1169/2011 zapewnienie „wysokiego poziomu ochrony zdrowia" uznane zostało za jeden z podstawowych celów m.in. znakowania. Jak wskazano, podawanie informacji na temat żywności służy wysokiemu poziomowi ochrony zdrowia przez zapewnienie konsumentom finalnym podstaw do dokonywania świadomych wyborów oraz bezpiecznego stosowania żywności, ze szczególnym uwzględnieniem uwarunkowań zdrowotnych (art. 3).

Znajduje to odzwierciedlenie zarówno w rozporządzeniu 1169/2011, stanowiącym akt prawny o istotnym znaczeniu dla znakowania żywności, określającym podstawowe wymogi w zakresie znakowania w odniesieniu do wszystkich produktów żywnościowych, jak i w przepisach szczegółowych mających zastosowanie wyłącznie do określonych środków spożywczych lub regulujących szczegółowe kwestie dotyczące znakowania żywności.

Spośród wymogów przewidzianych w rozporządzeniu 1169/2011 do instrumentów służących w zasadzie wyłącznie ochronie zdrowia i życia konsumentów należy zaliczyć obowiązek zamieszczania informacji o występowaniu w składzie żywności substancji lub produktów powodujących alergie lub reakcje nietolerancji (art. 9 ust. 1 lit. c), o terminie przydatności

7 K. Leśkiewicz, Prawo żywnościowe, Warszawa 2020, s. 38; P. Wojciechowski, Unijne prawo żywnościowe, w: M. Korzycka, P. Wojciechowski, System prawa ..., s. 125; B. van der Meulen, M. van der Velde, European Food Law Handbook, Wageningen 2008, s. 266; M. Korzycka-Iwanow, Prawo żywnościowe. Zarys prawa polskiego i wspólnotowego, Warszawa 2007, s. 94; wyrok TSUE z 5 maja 1998 r. w sprawie C-180/96 United Kingdom of Great Britain and Northern Ireland v. Commission of the European Communities, [1998] ECR, s. 2265. 
do spożycia (art. 9 ust. 1 lit. f), o specjalnych warunkach przechowywania lub warunkach użycia (art. 9 ust. 1 lit. g), o zawartości alkoholu w napojach powyżej 1,2\% (art. 9 ust. 1 lit. k) oraz o wartości odżywczej (art. 9 ust. 1 lit. 1). Poszczególne informacje mają różne znaczenie dla ochrony zdrowia, stąd prawodawca unijny przyjął różny zakres wymagań, a w szczególności wyjątków od ustalonych wymogów.

Wymogiem o charakterze bezwzględnym jest obowiązek zamieszczania informacji o występowaniu w składzie żywności substancji lub produktów powodujących alergie lub reakcje nietolerancji. Prawodawca unijny w tym przypadku uwzględnił fakt, że niektóre składniki lub inne substancje stosowane w produkcji żywności i pozostające po zakończeniu procesu produkcyjnego wywołują alergie lub reakcje nietolerancji u konsumentów, które stanowią bezpośrednie zagrożenie zdrowotne ${ }^{8}$. Wykaz substancji lub produktów wywołujących alergie lub reakcje nietolerancji został zamieszczony w załączniku nr II do rozporządzenia 1169/2011, a Komisja została zobowiązana do systematycznej analizy i w razie potrzeby uaktualniania wykazu w drodze aktów delegowanych, tak aby zapewnić konsumentom lepszą informację i uwzględnić najnowszą wiedzę naukową i techniczną (art. 21 ust. 2). Szczegółowo uregulowano też sposób zamieszczania tej informacji. W przypadku, gdy na etykiecie znajduje się wykaz składników (co jest zasadą), substancja lub produkt wywołujący alergie lub reakcje nietolerancji musi być w tym wykazie uwzględniony, a jego nazwa musi być podkreślona za pomocą pisma wyraźnie odróżniającego ją od reszty wykazu składników, np. za pomocą czcionki, stylu lub koloru tła (art. 21 ust. 1 lit. a i b). Jednak także w przypadku braku wykazu składników (co w drodze wyjątku bywa dopuszczone) oznaczenie na etykiecie musi obejmować słowo „zawiera”, po którym podana jest nazwa substancji lub produktu wywołującego alergie lub reakcje nietolerancji. Tego rodzaju informacje jako jedyne muszą być zamieszczone też na żywności nieopakowanej, mimo że co do zasady żywność nieopakowana wyłączona jest z zakresu obowiązków informacyjnych przewidzianych w rozporządzeniu 1169/2011, a regulacja w tym zakresie pozostawiona została prawodawcom krajowym ${ }^{9}$. Nie ulega wątpliwości, że obowiązkowo zamieszczana na etykiecie informacja o alergenach nie pełni funkcji promocyjnej, a obowiązek jej zamieszczania ma na celu dostarczenie jej konsumentom, którzy ze względu na swoje schorzenia nie mogą spożywać określonego rodzaju substancji lub produktów. Charakter promocyjny może mieć natomiast zamieszczenie dobrowolnej informacji o braku zawartości

\footnotetext{
${ }^{8}$ Zob. pkt 24 preambuly do rozporządzenia 1169/2011.

${ }^{9}$ Zob. art. 44 oraz pkt 48 preambuły do rozporządzenia 1169/2011.
} 
określonych substancji lub produktów wywołujących alergie lub reakcje nietolerancji. W przypadku tego rodzaju dobrowolnej informacji, mimo że jej zamieszczenie nakierowane jest na realizację interesów prywatnych, cel w postaci ochrony zdrowia i życia konsumentów realizowany jest w wymogu, aby informacja ta nie wprowadzała w błąd, co w przypadku tego rodzaju informacji musi oznaczać całkowity brak zawartości w produkcie oznakowanym taką informacją substancji lub produktów wywołujących alergie lub reakcje nietolerancji, których informacja dotyczy ${ }^{10}$.

Część środków spożywczych z mikrobiologicznego punktu widzenia charakteryzuje się tym, że szybko się psuje, i z tego względu już po krótkim czasie może stanowić bezpośrednie zagrożenie dla zdrowia ludzkiego. W odniesieniu do tego rodzaju żywności wprowadzony został obowiązek zamieszczania terminu przydatności do spożycia (podawana jest data poprzedzona informacją „należy spożyć do”) (art. 24 rozporządzenia 1169/2011). Prawodawca unijny przesądził też, że środki spożywcze po upływie terminu przydatności do spożycia są uznawane za niebezpieczne, co w konsekwencji oznacza, iż nie mogą być wprowadzane do obrotu (art. 14 ust. 1 rozporządzenia 178/2002). Informacja ta ma niezwykle istotne znaczenie dla ochrony zdrowia, a nawet życia konsumentów. Oczywiście upływ czasu jest tylko jednym z czynników, które należy uwzględnić przy ocenie bezpieczeństwa żywności, ale informacja o dacie przydatności do spożycia pozwala dokonać oceny bezpieczeństwa samemu konsumentowi. W przypadku tej informacji realizowany jest zatem wyłącznie cel w postaci ochrony zdrowia i życia konsumentów.

Należy jednocześnie zauważyć, że termin przydatności do spożycia jest jedną z możliwych informacji wykorzystujących datę. Istnieje bowiem obowiązek (od którego przewiduje się szereg wyjątków) zamieszczania daty minimalnej trwałości (poprzedzanej określeniem „najlepiej spożyć do”) na żywności, która ze względu na swoje właściwości nie musi być znakowana terminem przydatności do spożycia. Data minimalnej trwałości środka spożywczego oznacza datę, do której dany środek spożywczy zachowuje swoje szczególne właściwości pod warunkiem właściwego przechowywania go (art. 2 ust. 1 lit. r rozporządzenia 1169/2011). Stosowanie tych dwóch rodzajów dat na różnych rodzajach środków spożywczych - bez odpowiedniego wyedukowania konsumentów - prowadzi do tego, że duża część konsumentów nie rozróżnia tych dat ${ }^{11}$. Niespełna połowa obywateli UE

${ }^{10} \mathrm{P}$. Wojciechowski, Informacja o braku zawartości określonych substancji w żywności w regulacjach prawa żywnościowego, „Przegląd Prawa Rolnego” 2018, nr 1, s. 117.

${ }^{11}$ Ł.M. Sokołowski, O potrzebie całościowej regulacji prawnej przeciwdziałania marnowaniu żywności, „Przegląd Prawa Rolnego” 2019, nr 1, s. 61; Komunikat Komisji do Parlamentu Europejskiego, Rady, Europejskiego Komitetu Ekonomiczno-Społecznego i Komitetu Regionów, 
rozumie znaczenie oznaczeń „,najlepiej spożyć przed” i „należy spożyć do”"12, a sposób ich stosowania różni się w zależności od państwa członkowskiego, a także od producenta, przetwórcy i dystrybutora, nawet w przypadku tych samych produktów ${ }^{13}$. W Polsce do niezrozumienia tych dwóch pojęć prowadzi podobieństwo sformułowań „Należy spożyć do” oraz „Najlepiej spożyć przed" (podobne brzmienie, podobna długość fraz), a także przyczynia się do tego polskie prawodawstwo uznające, że środki spożywcze oznaczane datą minimalnej trwałości lub terminem przydatności do spożycia mogą znajdować się w obrocie do tej daty lub terminu ${ }^{14}$.

W konsekwencji przy obecnym stanie prawnym i istniejącej świadomości konsumentów powstaje rozbieżność między realizacją celu w postaci ochrony zdrowia i życia, czemu służyć ma termin przydatności do spożycia, a realizacją celu w postaci ochrony środowiska, czemu służy ograniczenie marnowania żywności, do którego z kolei przyczynia się równorzędne traktowanie przez konsumentów terminu przydatności do spożycia i daty minimalnej trwałości. W tym zakresie należy zatem postulować przede wszystkim zmianę polskiego ustawodawstwa zakazującego wprowadzania do obrotu żywności po upływie każdej z tych dat. Poza tym zasadne jest wprowadzenie zmian na szczeblu unijnym co do samej treści informacji odnoszących się do daty, tak aby informacje te w sposób pełniejszy i bardziej przejrzysty informowały konsumenta o ich znaczeniu. Pod uwagę można

Strategia „od pola do stołu” na rzecz sprawiedliwego, zdrowego i przyjaznego dla środowiska systemu żywnościowego, COM(2020) 381 final, s. 17.

${ }^{12}$ Inception Impact Assessment, Proposal for a revision of Regulation (EU) No 1169/2011 on the provision of food information to consumers, $\operatorname{Ares}(2020) 7905364,23 / 12 / 2020$, s. 2. Inicjatywa dotycząca zmiany przepisów UE na temat informacji przekazywanych konsumentom jest częścią unijnej strategii „od pola do stołu”, https://ec.europa.eu/info/law/better-regulation/have-your-say/ initiatives/12749-Etykietowanie-zywnosci-przeglad-przepisow-dotyczacych-informacji-przekazywanych-konsumentom_pl [dostęp: 7.10.2021].

${ }^{13}$ Rezolucja Parlamentu Europejskiego z 16 maja 2017 r. w sprawie inicjatywy dotyczącej efektywnego gospodarowania zasobami: ograniczenie marnotrawienia i zwiększenie bezpieczeństwa żywności (2016/2223(INI)), pkt AI. Jak pokazały badania rynkowe, zdarza się, że tego samego rodzaju produkty, a nawet identyczne produkty wytwarzane przez tego samego producenta, ale wprowadzane na terytorium różnych państwa członkowskich, w jednym państwie znakowane były datą minimalnej trwałości, a w innym terminem przydatności do spożycia. Zob. Market study on date marking and other information provided on food labels and food waste prevention Final Report, Directorate-General for Health and Food Safety, January 2018, s. iii, https://ec.europa.eu/ food/safety/food-waste/eu-actions-against-food-waste/date-marking-and-food-waste_en [dostęp: 7.10.2021].

${ }_{14}$ Zob. art. 52 ustawy o bezpieczeństwie żywności i żywienia (Dz. U. z 2006 r., Nr 171, poz. 1225 ze zm.). Co więcej, zgodnie z art. 100 ust. 1 pkt 1 tej samej ustawy: „Kto używa do produkcji lub wprowadza do obrotu środek spożywczy po upływie terminu przydatności do spożycia lub daty minimalnej trwałości, podlega karze grzywny”. 
brać zarówno dodanie dodatkowych treści (np. w przypadku daty minimalnej trwałości można byłoby wprowadzić dodatkowy dopisek zamieszczany po dacie: „ale można także spożyć po” lub rozważyć zupełnie nowe brzmienie dla daty minimalnej trwałości, np. „najlepsza jakość przed”), wprowadzenie specjalnych znaków graficznych (piktogramów lub symboli, np. termin przydatności do spożycia wpisany w znak ,stop”) czy narzucenie konkretnych kolorów dla tych dwóch rodzajów informacji (taką metodę wykorzystano dla rozróżnienia oznakowania chronionego oznaczenia geograficznego od chronionej nazwy pochodzenia, gdzie ze względu na podobieństwo znaków graficznych konsumenci mieli trudności z rozróżnieniem produktów znakowanych tymi dwoma rodzajami oznaczeń).

W przypadku tych rodzajów żywności, które wymagają specjalnego przechowywania, niezależnie od podania terminu przydatności albo daty minimalnej trwałości konieczne jest podanie informacji o specjalnych warunkach przechowywania lub warunkach użycia. Informacja ta stanowi istotne uzupełnienie informacji o terminie przydatności do spożycia lub daty minimalnej trwałości, bowiem środek spożywczy zachowa swoje właściwości do podanego terminu przydatności do spożycia lub daty minimalnej trwałości tylko wtedy, gdy będzie przechowywany we właściwych warunkach (np. w warunkach chłodniczych). W przypadku żywności opatrzonej terminem przydatności do spożycia informacja ta jest kluczowa dla zapewnienia bezpieczeństwa żywności, a zatem realizuje ona cel w postaci ochrony zdrowia lub życia. Z kolei w przypadku żywności opatrzonej datą minimalnej trwałości chodzi o ochronę interesów ekonomicznych konsumentów.

Powszechnie znane są szkodliwe skutki spożywania alkoholu, zwłaszcza dla młodych i szczególnie podatnych na zagrożenie konsumentów ${ }^{15}$. Jak się zauważa, alkohol jest największym czynnikiem ryzyka - większym nawet niż używanie tytoniu - dla występowania na całym świecie chorób wśród osób w wieku od 15 do 49 lat ${ }^{16}$. Szkodliwe skutki spożywania alkoholu są istotnym problemem dotyczącym zdrowia publicznego w $\mathrm{UE}^{17}$. Jednocześnie

15 Zob. m.in. Konkluzje Rady w sprawie strategii UE w zakresie ograniczania szkodliwych skutków spożywania alkoholu (2015/C 418/03) (Dz. Urz. UE C 418 z 16.12.2015 r., s. 6 ze zm.); Konkluzje Rady - Transgraniczne aspekty polityki alkoholowej - zwalczanie szkodliwego używania alkoholu (Dz. Urz. C 441 z 22.12.2017 r., s. 3 ze zm.); Opinia Europejskiego Komitetu Regionów - W kierunku europejskiej strategii dotyczącej alkoholu (2017/C 207/12) (Dz. Urz. C 207 z 30.06.2017 r., s. 61 ze zm.); Sprawozdanie Komisji dla Parlamentu Europejskiego i Rady w sprawie obowiązkowego podawania wykazu składników i informacji o wartości odżywczej na etykietach napojów alkoholowych, COM/2017/058 final.

${ }^{16}$ Opinia Europejskiego Komitetu Regionów - W kierunku europejskiej strategii...

17 Komunikat Komisji do Parlamentu Europejskiego i Rady, Europejski plan walki z rakiem, Bruksela, 3.02.2021 r., $\operatorname{COM(2021)~} 44$ final. 
w rozporządzeniu 1169/2011 wprowadzono jedynie obowiązek zamieszczenia informacji o rzeczywistej zawartości alkoholu w odniesieniu do napojów o zawartości alkoholu większej niż 1,2\% objętościowo (art. 9 ust. 1 lit. k). Co więcej, w tego rodzaju napojach nie ma obowiązku podawania wykazu składników ani informacji o wartości odżywczej (art. 16 ust. 4).

Niewątpliwie obowiązek zamieszczenia informacji o zawartości alkoholu ma dostarczyć konsumentom informacji, dzięki którym będą mogli dokonać świadomego wyboru co do spożycia alkoholu, a zatem obowiązek ten ma na celu ochronę zdrowia i życia. Na krytykę zasługuje jednak wyłączenie w odniesieniu do napojów zawierających powyżej 1,2\% alkoholu obowiązku podania wykazu składników (z wyjątkiem składników, mogących powodować alergie, które muszą być podane) oraz wartości odżywczej. Komisja w 2017 r. podkreśliła, że nie dostrzega obiektywnych podstaw, które uzasadniałyby brak informacji o składnikach i wartości odżywczej napojów alkoholowych, przy czym uznała, że zważywszy na to, iż sektor producentów napojów alkoholowych jest w coraz większym stopniu przygotowany do reagowania na oczekiwania konsumentów, którzy chcą wiedzieć, co piją, zasadne jest pozostawienie dalszego rozwoju obecnych inicjatyw dobrowolnych, tak aby zapewnić podawanie wykazu składników i informacji o wartości odżywczej na zasadzie samoregulacji ${ }^{18}$.

Z uwagi na ochronę zdrowia i życia konsumentów podawanie pełnych informacji, w tym o składnikach i wartości odżywczej napojów zawierających powyżej 1,2\% alkoholu, jest w pełni uzasadnione. Co więcej, tego rodzaju napoje powinny być opatrzone dodatkowymi obowiązkowymi ostrzeżeniami dotyczącymi ryzyka związanego ze spożywaniem alkoholu, w tym - na co zwracał uwagę Europejski Komitetu Regionów - ostrzeżeniami dla kobiet ciężarnych, młodzieży oraz kierowców ${ }^{19}$. Warto zaznaczyć, że w 2021 r. Komisja zapowiedziała, iż przedstawi propozycję obowiązkowego podawania wykazu składników i informacji o wartości odżywczej oraz - przed końcem 2023 r. - ostrzeżeń zdrowotnych na etykietach napojów alkoholowych ${ }^{20}$. Ochronie zdrowia i życia służą też ograniczenia co do możliwości stosowania oświadczeń żywieniowych i zdrowotnych na napojach o zawartości alkoholu większej niż 1,2\% objętości. Tego rodzaju napoje nie mogą być opatrywane oświadczeniami zdrowotnymi, a jeśli chodzi o oświadczenia

18 Sprawozdanie Komisji dla Parlamentu Europejskiego i Rady w sprawie obowiązkowego podawania wykazu składników i informacji o wartości odżywczej na etykietach napojów alkoholowych, COM/2017/058 final.

${ }^{19}$ Opinia Europejskiego Komitetu Regionów - W kierunku europejskiej strategii...,pkt 44-47.

${ }^{20}$ Komunikat Komisji do Parlamentu Europejskiego i Rady, Europejski plan walki z rakiem..., s. 11. 
żywieniowe, dopuszczalne są jedynie oświadczenia odnoszące się do niskiego stężenia alkoholu, zmniejszonej zawartości alkoholu lub zmniejszonej zawartości energetycznej napojów zawierających ponad 1,2\% objętości alkoholu (art. 4 ust. 3 rozporządzenia 1924/2006).

Istotnym czynnikiem kształtującym nawyki żywieniowe są informacje uzyskiwane przez konsumenta, które wpływają na decyzje dotyczące kupowanych produktów spożywczych, a wskazanie wartości odżywczej (obejmującej informację o wartości energetycznej oraz o ilości tłuszczu, kwasów tłuszczowych nasyconych, węglowodanów, cukrów, białka oraz soli) jest uznawane za jeden ze sposobów przekazywania informacji konsumentom w celu wspierania podejmowania przez nich właściwych decyzji przy zakupie produktów spożywczych i napojów ${ }^{21}$. Znajomość podstawowych zasad żywienia oraz odpowiednich informacji żywieniowych na temat środków spożywczych pozwala konsumentom podejmować świadome wybory22. Obowiązkowe podawanie informacji żywieniowych jest instrumentem wspierającym działania dotyczące żywienia, a przez to stanowi ważny element polityki zdrowia publicznego, obok edukacji czy wydawania zaleceń nauko$w_{y c h}{ }^{23}$. Istotne przy tym jest to, aby przekazywane informacje żywieniowe przemawiały do przeciętnego konsumenta i służyły celowi informacyjnemu, w którym je wprowadzono, a zatem ochronie zdrowia konsumentów, w związku z czym powinny być proste i zrozumiałe ${ }^{24}$. Dla zapewnienia precyzji i jednoznaczności informacji o wartości odżywczej w rozporządzeniu 1169/2011 szczegółowo uregulowano zakres informacji, sposób jej wyrażania (w tym w przeliczeniu na $100 \mathrm{~g}$, na $100 \mathrm{ml}$ lub na porcję) oraz sposób prezentacji, a jednocześnie dopuszczono dodatkowe dobrowolne formy wyrażania i prezentacji informacji o wartości odżywczej (np. formy graficzne lub symbole), które można zamieszczać na przodzie opakowania, pod warunkiem że są zgodne z kryteriami określonymi w rozporządzeniu 1169/2011 (m.in. mają ułatwiać konsumentowi zrozumienie znaczenia danej żywności dla zawartości energii i składników odżywczych w diecie oraz muszą opierać się na rzetelnych, naukowo uzasadnionych badaniach konsumenckich i nie mogą wprowadzać konsumenta w błąd), a państwa członkowskie mogą zalecać ich wykorzystywanie (art. 35). Kilka państw unijnych zatwierdziło lub rozważa zatwierdzenie systemów o różnym charakterze, począwszy od uproszczonych sprowadzających się do pozytywnego

${ }^{21}$ Biała Księga, Strategia dla Europy w sprawie zagadnień zdrowotnych związanych z odżywianiem, nadwagą i otyłością, Bruksela, 30.05 .2007 r., $\operatorname{KOM(2007)~279,~wersja~ostateczna,~s.~} 6$.

${ }^{22}$ Pkt 10 preambuły rozporządzenia 1169/2011.

${ }^{23}$ Pkt 34 preambuly rozporządzenia 1169/2011.

${ }^{24}$ Pkt 40 preambuły rozporządzenia 1169/2011. 
$\operatorname{logo}^{25}$, poprzez etykiety uproszczone obejmujące stopniowane wskaźniki ${ }^{26}$, na etykietach przedstawiających poszczególne składniki odżywcze kończąc ${ }^{27}$. Komisja w sprawozdaniu w sprawie stosowania dodatkowych form wyrażania i prezentacji informacji o wartości odżywczej zaprezentowała wynik obszernych badań konsumenckich i zwróciła uwagę na szereg czynników, które wpływają na skuteczność przekazu dotyczącego informacji na temat wartości odżywczej, takich jak: miejsce umieszczenia informacji na opakowaniu, jej wielkość, użyte kolory, atrakcyjność informacji. Jak zauważyła, wyniki badań potwierdzają, że systemy oznaczania wartości odżywczych na przodzie opakowania mogą ułatwiać konsumentom dokonywanie świadomych wyborów żywieniowych, a zatem jest im łatwiej wybrać zdrowszy produkt spożywczy ${ }^{28}$.

$\mathrm{Na}$ ochronę zdrowia i życia człowieka nastawiona jest także regulacja oświadczeń żywieniowych i zdrowotnych zawarta w rozporządzeniu 1924/2006 ${ }^{29}$, którego wydanie stanowiło odpowiedź na coraz częstsze wykorzystywanie przez producentów dla wyróżnienia swoich produktów informacji wskazujących na szczególne właściwości wynikające z jego właściwości odżywczych lub z powiązania spożywania określonego środka spożywczego ze stanem zdrowia ${ }^{30}$. Żywność, która jest promowana przy użyciu odpowiednich oświadczeń, może być bowiem postrzegana przez konsumentów jako produkt o korzystniejszych właściwościach odżywczych, fizjologicznych lub zdrowotnych niż podobne lub inne produkty, do których takie składniki

${ }^{25}$ W 1989 r. w Szwecji przyjęto logo Keyhole („dziurka od klucza”), wprowadziły je także Dania i Litwa, w 2000 r. Finlandia zatwierdziła logo „Symbol serca - lepszy wybór”, w Słowenii w 1992 r. przyjęto logo „Żywność, która chroni”.

${ }^{26}$ W październiku 2017 r. Francja, po przeprowadzeniu wielu badań eksperymentalnych na dużą skalę, przyjęła system Nutri-Score. Etykieta stanowi skalę pięciu kolorów - od ciemnozielonego, który oznacza produkty spożywcze o najwyższej wartości odżywczej, do ciemnopomarańczowego, oznaczającego produkty o niższej wartości odżywczej; kolory powiązane są z literami od A do E.

27 W styczniu 2020 r. Włochy powiadomiły Komisję o projekcie rozporządzenia, w którym zalecono stosowanie na przodzie opakowania dobrowolnego systemu „Bateria NutrInform”. System ten opiera się na etykiecie zawierającej referencyjne wartości spożycia z dodanym symbolem baterii wskazującym ilość energii i składników odżywczych w jednej porcji jako odsetek dziennego spożycia. W 2013 r. Zjednoczone Królestwo, po kilku latach badań naukowych i konsultacji z zainteresowanymi stronami, formalnie wprowadziło dobrowolny system oznaczania wartości odżywczych na przodzie opakowania, tzw. system oparty na „modelu sygnalizacji świetlnej”.

${ }^{28}$ Sprawozdanie Komisji dla Parlamentu Europejskiego i Rady w sprawie stosowania dodatkowych form wyrażania i prezentacji informacji o wartości odżywczej, COM/2020/207 final.

29 Rozporządzenie Parlamentu Europejskiego i Rady (WE) nr 1924/2006 z 20 grudnia 2006 r. w sprawie oświadczeń żywieniowych i zdrowotnych dotyczących żywności (Dz. Urz. UE L 404 z 30.12.2006 r., s. 9 ze zm.).

${ }^{30}$ Pkt 1 preambuły do rozporządzenia 1924/2006. 
odżywcze i inne substancje nie zostały dodane. W konsekwencji może to skłaniać konsumentów do podejmowania decyzji, które bezpośrednio wpłyną na całkowitą ilość spożywanych przez nich poszczególnych składników odżywczych lub innych substancji w sposób, który byłby niezgodny z zaleceniami naukowymi, co stanowiło uzasadnienie dla wprowadzenia regulacji dotyczącej oświadczeń żywieniowych i zdrowotnych ${ }^{31}$.

Ochrona zdrowia i życia stanowiła też uzasadnienie dla wprowadzenia regulacji dotyczącej informowania o braku zawartości glutenu, jak i szczególnych wymogów co do znakowania suplementów diety, preparatów do początkowego żywienia niemowląt oraz preparatów do dalszego żywienia niemowląt, żywności specjalnego przeznaczenia medycznego i środków spożywczych zastępujących całodzienną dietę, do kontroli masy ciała.

Do zapewnienia ochrony zdrowia przyczynia się ponadto wprowadzony w rozporządzeniu 1169/2011 zakaz prezentowania dobrowolnych informacji na temat żywności ze szkodą dla przestrzeni dostępnej do prezentacji obowiązkowych informacji na temat żywności (art. 37).

\section{Ochrona interesów konsumentów i rzetelności obrotu}

Ochrona interesów ekonomicznych konsumentów w zakresie obrotu żywnością została $\mathrm{w}$ prawie żywnościowym ściśle powiązana $\mathrm{z}$ ochroną uczciwych praktyk w handlu żywnością ${ }^{32}$. Cel ten znajduje uzasadnienie nie tylko w treści rozporządzenia 178/2002, ale także w przepisach traktatowych (art. $12 \mathrm{i}$ art. 169 TFUE) oraz w wielu innych przepisach prawa żywnościowego.

W rozporządzeniu nr 1169/2011 wprost wskazano, że stanowi ono podstawę zapewnienia „wysokiego poziomu ochrony konsumentów” w zakresie informacji na temat żywności, przy uwzględnieniu różnic percepcji ze strony konsumentów i ich potrzeb informacyjnych (art. 1 ust. 1), oraz że ustanawia środki gwarantujące konsumentom prawo do informacji i procedury przekazywania informacji na temat żywności (art. 1 ust. 1). Poza tym za cel podawania informacji na temat żywności uznano wysoki poziom ochrony zdrowia i interesów konsumentów przez zapewnienie konsumentom finalnym podstaw do dokonywania świadomych wyborów oraz bezpiecznego stosowania żywności, ze szczególnym uwzględnieniem uwarunkowań

${ }^{31}$ Pkt 10 preambuły do rozporządzenia 1924/2006.

32 Art. 5 rozporządzenia nr 178/2002, w którym jako zadanie prawa żywnościowego wskazuje się realizację ,celów dotyczących [...] ochrony interesów konsumentów, z uwzględnieniem uczciwych praktyk w handlu żywnością [...]”. 
zdrowotnych, ekonomicznych, środowiskowych, społecznych i etycznych (art. 3 ust. 1). O ile na gruncie rozporządzenia 178/2002 za podstawowy cel całego prawa żywnościowego, a więc także przepisów dotyczących informowania o żywności, uznano „,wysoki poziom ochrony zdrowia i życia”, o tyle w rozporządzeniu 1169/2011 w odniesieniu do tej części prawa żywnościowego, która obejmuje przepisy regulujące informacje na temat żywności ${ }^{33}$, „wysoki poziom ochrony" odniesiono nie tylko do ochrony zdrowia, ale także do „interesów konsumentów”"34, a zatem zrównano potrzebę ochrony zdrowia i interesów konsumentów. Jednocześnie zastrzeżono, iż w przepisach dotyczących informacji na temat żywności konieczne jest uwzględnienie ochrony słusznych interesów producentów (art. 3 ust. 2).

Regulacja dotycząca znakowania żywności ma zatem na celu ochronę interesów konsumentów i rzetelności obrotu i w istocie większość przepisów dotyczących informacji na temat żywności zawiera różnego rodzaju instrumenty służące realizacji tych celów.

Ochronie konsumentów i rzetelności obrotu mają służyć podstawowe zasady przyjęte w rozporządzeniu 1169/2001 dotyczące informacji na temat żywności, tj. obowiązek zamieszczenia informacji na temat żywności na każdym środku spożywczym oraz wymóg, aby informacje na temat żywności, w tym etykieta, nie wprowadzały w błąd oraz były rzetelne, jasne i łatwe do zrozumienia dla konsumenta (art. 6-7). W przypadku informacji na temat żywności przekazywanych na zasadzie dobrowolności pojawia się dodatkowy wymóg, aby nie były niejednoznaczne i nie dezorientowały konsumenta oraz były oparte na odpowiednich danych naukowych i nie były prezentowane ze szkodą dla przestrzeni dostępnej do prezentacji obowiązkowych informacji na temat żywności (art. 36-37).

Ochronie konsumentów i rzetelności obrotu służy też duża część wymagań szczegółowych, w tym dotyczących dostępności i sposobu zamieszczania obowiązkowych informacji na temat żywności (art. 12), przedstawiania informacji na temat żywności, wymagań językowych czy wymagań przy sprzedaży na odległość (art. 13-15), a także szczegółowa regulacja dotycząca poszczególnych informacji obowiązkowych.

${ }^{33}$ W rozporządzeniu 1169/2011 część prawa żywnościowego obejmującą przepisy unijne regulujące informacje na temat żywności określa się jako ,prawo dotyczące informacji na temat żywności" (art. 2 ust. 2 lit. b).

${ }^{34}$ Należy zwrócić uwagę na odmienność sformułowania w rozporządzeniu 1169/2011, gdzie mowa jest o „wysokim poziomie ochrony zdrowia i interesów konsumentów” w stosunku do sformułowania użytego przy określeniu celów prawa żywnościowego w rozporządzeniu 178/2002, gdzie mowa jest o celach „dotyczących wysokiego poziomu ochrony zdrowia i życia ludzi oraz ochrony interesów konsumentów". 
Ochrona konsumentów i rzetelności obrotu stanowi też uzasadnienie dla wprowadzenia regulacji dotyczącej znakowania żywności ekologicznej, żywności regionalnej i tradycyjnej (chronione oznaczenie geograficzne, chroniona nazwa pochodzenia, gwarantowana tradycyjna specjalność) czy żywności zawierającej GMO, niezależnie od istnienia innych przesłanek dla wprowadzenia tego rodzaju regulacji szczegółowych. Warto zwrócić uwagę, że choć wprowadzenie niektórych wymogów dotyczących znakowania żywności może być motywowane przesłankami odnoszącymi się do ochrony zdrowia (np. wartość energetyczna, bezglutenowe, oświadczenia żywieniowe i zdrowotne), ochrony środowiska (np. eko), to jednocześnie regulacje te służą ochronie interesu konsumenta, a także zapewnieniu rzetelności obrotu. Zważywszy bowiem na funkcję promocyjną etykiet żywności, producenci mogą wykorzystywać wszelkie informacje (zwykle dotyczy to informacji dobrowolnych), w tym odnoszące się do ochrony zdrowia czy do środowiska, dla wyróżnienia swoich produktów. W takim przypadku zasady dotyczące przejrzystości i jasności oraz niewprowadzania konsumentów w błąd wyznaczają dopuszczalny zakres zamieszczania informacji nakierowanych na ochronę zdrowia czy środowiska.

\section{Ochrona środowiska oraz ochrona zdrowia i dobrostanu zwierząt}

Ochrona środowiska oraz ochrona zdrowia i dobrostanu zwierząt zostały wyrażone w rozporządzeniu 178/2002 jako odrębne cele prawa żywnościowego. Traktatowe podstawy polityki ochrony środowiska zawarte są w art. 11 i art. 191-193 TFUE. Ochrona środowiska jest przedmiotem jednej z najważniejszych polityk unijnych, a na jej kształt istotny wpływ ma konieczność pogodzenia rozwoju gospodarczego i społecznego z wymogami ochrony środowiska ${ }^{35}$. Z kolei ochrona zdrowia i dobrostanu zwierząt znajduje uzasadnienie traktatowe $\mathrm{w}$ art. $13 \mathrm{i}$ art. 36 TFUE.

Ochrona środowiska i dobrostanu zwierząt w prawie żywnościowym realizowana jest przede wszystkim przez regulację dotyczącą produkcji ekologicznej. Potrzeba ochrony środowiska, obok wzrostu popytu na produkty ekologiczne, przyczyniła się do wydania na szczeblu wspólnotowym na początku lat 90. pierwszej regulacji prawnej dotyczącej bezpośrednio rolnictwa ekologicznego ${ }^{36}$. Należy podkreślić, że od wielu lat obserwowany

${ }^{35}$ M. Nowacki, A. Przyborowska-Klimczak, w: A. Wróbel (red.), Traktat o funkcjonowaniu Unii Europejskiej. Komentarz, t. 2, Warszawa 2012, s. 1265.

${ }^{36}$ M. Korzycka, P. Wojciechowski, Żywność ekologiczna w prawie USA i Unii Europejskiej, „Studia Iuridica Agraria” 2015, t. XIII, s. 21. 
jest wzrost świadomości środowiskowej konsumentów i wagi, jaką przywiązują do sposobu wytworzenia produktu ${ }^{37}$. Jednocześnie ekologiczne metody produkcji sprzyjają utrzymaniu żyzności gleby i ochronie środowiska przed skażeniami i zanieczyszczeniami pochodzenia rolniczego, przyczyniają się do ochrony wód gruntowych i zachowania naturalnego krajobrazu oraz pozwalają zachować równowagę biologiczną w środowisku przyrodniczym ${ }^{38}$. Od chwili wprowadzenia regulacji dotyczącej produkcji ekologicznej podkreśla się korzyści płynące z ekologicznych metod produkcji dla środowiska, dobrostanu zwierząt i zrównoważonego rozwoju obszarów wiejskich, celem regulacji stała się też ochrona środowiska ${ }^{39}$. Regulacja dotycząca znakowania żywności wytworzonej metodą ekologiczną z jednej strony nakierowana jest więc na ochronę interesów konsumentów, poszukujących określonego rodzaju produktów, z drugiej - promowanie tego rodzaju produktów i wyróżnianie produktów oznaczeniem „eko” wpływa na kształtowanie zachowań konsumenckich, przez co realizowany jest cel w postaci ochrony środowiska, a pomocniczo także ochrony dobrostanu zwierząt.

Do regulacji z zakresu prawa żywnościowego dotyczących znakowania, które przyczyniają się do ochrony środowiska, należy zaliczyć także regulację dotyczącą żywności regionalnej i tradycyjnej. Te publiczne systemy jakości żywności promują produkty, które posiadają cechy będące „szczególną zasługą środowiska geograficznego" (art. 5 ust. 1 lit. b rozporządzenia nr 1151/2012), co ma związek także ze stanem środowiska. Stosowanie oznaczeń: chroniona nazwa pochodzenia, chronione oznaczenie geograficzne czy gwarantowana tradycyjna specjalność ma wpływ na wybory konsumenckie, a pośrednio także na środowisko, przy czym w przeciwieństwie do regulacji produkcji ekologicznej w tym przypadku ten związek nie jest bezpośredni.

Z kolei ochronie dobrostanu zwierząt mają służyć wymogi dotyczące znakowania jaj informacją o warunkach chowu kur (chów klatkowy, ściółkowy, wolny wybieg), a w pewnym zakresie także informacja o kraju urodzenia, chowu i uboju niektórych zwierząt.

Jak jednak zauważa Komisja w komunikacie „Strategia »od pola do stołu« na rzecz sprawiedliwego, zdrowego i przyjaznego dla środowiska

${ }^{37}$ L. Kaźmierczak-Piwko, A. Dybikowska, E. Celińska, J. Ratajczak, Rola ekoznakowania produktów konsumpcyjnych w podnoszeniu świadomości ekologicznej nabywców, „Problemy w Zarządzaniu Środowiskiem” 2017, nr 7, s. 123.

${ }^{38}$ D. Komorowska, Ekonomika produkcji ekologicznej w Polsce, „Zeszyty Naukowe SGGW: Ekonomika i Organizacja Gospodarki Żywnościowej” 2009, nr 73, s. 143.

39 Zob. akapit 2 preambuły do rozporządzenia 2092/91 oraz pkt 1 i $12-16$ preambuły do rozporządzenia 834/2007; pkt 5 preambuły rozporządzenia nr 2018/848. 
systemu żywnościowego" ${ }^{40}$, wzorce konsumpcji żywności są niezrównoważone z punktu widzenia środowiska, a celem UE jest zmniejszenie śladu środowiskowego i klimatycznego unijnego systemu żywnościowego ${ }^{41}$. W dokumencie tym Komisja zapowiedziała, że zbada sposoby zharmonizowania dobrowolnych twierdzeń dotyczących ekologiczności i stworzenia ram zrównoważonego etykietowania obejmujących aspekty odżywcze, klimatyczne, środowiskowe i społeczne produktów spożywczych ${ }^{42}$. Jest to o tyle istotna zapowiedź, że tzw. etykiety środowiskowe są od wielu lat stosowane przez podmioty działające na rynku spożywczym, przy czym większość obecnych na rynku oznaczeń środowiskowych skupia się na śladzie węglowym $\left(\mathrm{CO}_{2}\right)$ i jest stosowana przez podmioty prywatne na zasadzie dobrowolności ${ }^{2}{ }^{4}$. Jak się podkreśla, oznakowanie na środku spożywczym może być skutecznym narzędziem regulacyjnym w zachęcaniu do dokonywania wyborów przyjaznych dla środowiska ${ }^{44}$. Badania konsumenckie wskazują przy tym, że konsumenci są zainteresowani informacją o śladzie węglowym, jednak uzgodnienie jednego formatu takiej informacji, a tym bardziej sposobu wyliczania jest niezwykle problematyczne ${ }^{45}$.

W tym kontekście należy stwierdzić, że brak regulacji dotyczącej znakowania żywności informacją środowiskową inną niż odnoszącą się do produkcji ekologicznej powoduje, że konsumenci mogą być informowani o wybranych aspektach powiązanych ze środowiskiem (np. o śladzie węglowym, tj. sumie gazów cieplarnianych emitowanych w łańcuchu żywnościowym, o wpływie na przyrodę - przez znak Rainforest Alliance, czy o pochodzeniu produktu ze zrównoważonych upraw - przez znak UTZ Certified), przy braku pełnej informacji o oddziaływaniu na środowisko w pozostałym zakresie. Stosowanie tego rodzaju dobrowolnych oznaczeń odpowiada co prawda na potrzeby konsumentów, ale nie stanowi optymalnego rozwiązania w sferze ochrony środowiska. Co więcej, zważywszy na promocyjną funkcję etykiet żywności, istnieje ryzyko nadużywania informacji środowiskowych wyłącznie w celu

${ }^{40}$ Komunikat Komisji do Parlamentu Europejskiego, Rady, Europejskiego Komitetu Ekonomiczno-Społecznego i Komitetu Regionów, Strategia „od pola do stołu” na rzecz sprawiedliwego, zdrowego i przyjaznego dla środowiska systemu żywnościowego, COM(2020) 381 final.

${ }^{41}$ Ibidem, s. 5.

${ }^{42}$ Ibidem, s. 16.

${ }^{43}$ L. Muller, A. Lacroix, B. Ruffieux, Environmental Labelling and Consumption Changes: A Food Choice Experiment, „Environmental and Resource Economics” 2019, Vol. 73, issue 3, https://link.springer.com/article/10.1007/s10640-019-00328-9 [dostęp: 8.10.2021].

44 J.J. Czarnezki, The Future of Food Eco-Labeling: Organic, Carbon Footprint, and Environmental Life-Cycle Analysis, „Stanford Environmental Law Journal” 2011, Vol. 30, No. 3, http:// digitalcommons.pace.edu/lawfaculty/914/ [dostęp: 8.10.2021], s. 4.

${ }^{45}$ L. Muller, A. Lacroix, B. Ruffieux, Environmental Labelling..., passim. 
uzyskania przewagi rynkowej (greenwashing), bez uwzględnienia celu podstawowego, tj. ochrony środowiska.

Obecnie obserwuje się również wzrost zainteresowania konsumentów dietą bezmięsną lub pozbawioną całkowicie produktów pochodzenia zwierzęcego, czego wyrazem było zgłoszenie inicjatywy obywatelskiej „Obowiązkowe znakowanie środków spożywczych jako niewegetariańskie/wegetariańskie/ wegańskie" ${ }^{46}$. Pojawiają się też informacje dotyczące sposobu chowu zwierząt, w tym ich żywienia (np. grass fed beef), z czego regulacji prawnej poddane jest jedynie znakowanie jaj. Także w tym przypadku brak regulacji może prowadzić do ograniczonej realizacji celu, jakim jest ochrona środowiska, jak również celu, jaki stanowi ochrona dobrostanu zwierząt.

Co więcej, nacisk położony na informacje środowiskowe czy związane z ochroną zwierząt, zwłaszcza gdy sposób prezentowania tego rodzaju informacji będzie zbliżony do dobrowolnych systemów informacji o wartości odżywczej, może prowadzić do zmniejszenia koncentracji konsumentów na kwestii ochrony zdrowia. Dlatego podjęcie przez Komisję działań zmierzających do stworzenia ram zrównoważonego etykietowania, obejmujących aspekty odżywcze, klimatyczne, środowiskowe oraz społeczne produktów spożywczych, jest w pełni uzasadnione.

\section{Podsumowanie}

Znakowanie żywności odgrywa istotną rolę w realizacji celów prawa żywnościowego. Etykieta jest przede wszystkim nośnikiem informacji o produkcie (funkcja informacyjna), dzięki czemu umożliwia komunikację między producentem a konsumentem. Nie można jednak zapominać, że etykieta jest też sposobem wyróżnienia produktu i zdobycia przewagi konkurencyjnej przez producenta (funkcja promocyjna), stąd konieczna jest regulacja prawna, która $\mathrm{z}$ jednej strony zapewni dostęp do niezbędnych informacji, a z drugiej - będzie chronić konsumenta przed wprowadzeniem w błąd. Warto także zauważyć, że etykieta pozwala na realizowanie określonych celów publicznych poprzez zwracanie uwagi konsumentów na informacje istotne dla ich realizacji (funkcja edukacyjna, publiczna).

$\mathrm{Na}$ gruncie prawa żywnościowego wszystkie te trzy cechy znakowania są wykorzystywane do realizacji celów prawa żywnościowego. Lista informacji obowiązkowych, jakie muszą być zamieszczone na opakowaniu żywności,

${ }^{46}$ Decyzja Komisji (UE) 2018/1701 z 7 listopada 2018 r. w sprawie proponowanej inicjatywy obywatelskiej „Obowiązkowe znakowanie środków spożywczych jako niewegetariańskie/ wegetariańskie/wegańskie" (Dz. Urz. UE L 285/80 ze zm.). 
z jednoczesnym dopuszczeniem informacji dobrowolnych, które nie mogą jednak wprowadzać w błąd, daje gwarancję, że konsument uzyska pełną informację o produkcie. Zakres informacji obowiązkowych nakierowany jest na realizację dwóch celów: ochronę zdrowia i życia konsumentów oraz ochronę interesów ekonomicznych i rzetelności obrotu. Konsument, zapoznając się z informacjami obowiązkowymi, dowiaduje się o podstawowych cechach środka spożywczego, w tym o ewentualnych zagrożeniach dla zdrowia (alergeny) czy o wartości odżywczej, ale także o podstawowych cechach jakościowych (wykaz składników, producent, ilość). Również szczególna regulacja dotycząca niektórych rodzajów żywności oraz oświadczeń żywieniowych i zdrowotnych ma na celu ochronę zdrowia i życia. Są jednak zagadnienia będące poza zakresem regulacji, co do których powinny być wprowadzone zmiany, dotyczące np. znakowania napojów alkoholowych. Poza tym wymagana jest zmiana w zakresie znakowania żywności datą minimalnej trwałości, gdyż obecna regulacja - zarówno unijna, jak i w poszczególnych krajach - nakierowana jest na ochronę zdrowia konsumentów, a pomija konsekwencje środowiskowe wynikające z marnowania żywności niestwarzającej zagrożenia dla życia lub zdrowia i nadającej się do spożycia przez ludzi, której data minimalnej trwałości upłynęła.

Jednocześnie obowiązująca regulacja w zakresie obowiązkowego znakowania, w połączeniu z kluczowymi zasadami rzetelności, jasności, łatwości zrozumienia etykiet i niewprowadzania konsumentów w błąd, chroni interes ekonomiczny konsumenta oraz zabezpiecza uczestników łańcucha żywnościowego przed nieuczciwymi praktykami handlowymi. Cel ten realizowany jest też wieloma regulacjami służącymi w pierwszym rzędzie ochronie zdrowia lub życia konsumentów.

Z kolei ochrona środowiska i ochrona dobrostanu zwierząt są celami realizowanymi w zasadzie wyłącznie przez regulacje szczegółowe, przy czym zakres tych regulacji - w stosunku do zakresu informacji oczekiwanych przez konsumentów, ale także z uwagi na możliwy większy wpływ rzetelnych informacji na zachowania konsumenckie służące ochronie środowiska - wydaje się niewystarczający. Podmioty prowadzące przedsiębiorstwa spożywcze, odpowiadając na zapotrzebowanie rynkowe, zaczęły wdrażać różnego rodzaju prywatne systemy jakości, powiązane z oznakowaniem środowiskowym. Jednak wielość tych systemów, konkurencja między nimi, a także brak jednolitych kryteriów wprowadzania określonych informacji (np. o zmniejszeniu śladu węglowego) powoduje, że zarówno ochrona środowiska, jak i ochrona zwierząt nie są na chwilę obecną realizowane w optymalnym, zrównoważonym stopniu. Co więcej, nadmiar informacji 
środowiskowych i odnoszących się do dobrostanu zwierząt może negatywnie wpływać na realizację pozostałych celów.

Zważywszy na potrzebę podjęcia działań realnie przyczyniających się do ochrony środowiska, ale z uwzględnieniem pozostałych celów prawa żywnościowego, konieczne wydaje się ustalenie unijnych ram stosowania na środkach spożywczych informacji związanych ze środowiskiem. Wzorem mogłaby być w tym zakresie regulacja oświadczeń żywieniowych. Oświadczenia środowiskowe mogłyby być stosowane na zasadzie dobrowolności, ale wyłącznie w określonej ujednoliconej formie (z ewentualnymi zastrzeżeniami), przy zachowaniu ramowo ustalonych wymogów dotyczących produktu, np. sposobu jego wytworzenia.

\section{BIBLIOGRAFIA}

Czarnezki J.J. (2011), The Future of Food Eco-Labeling: Organic, Carbon Footprint, and Environmental Life-Cycle Analysis, „Stanford Environmental Law Journal” Vol. 30, No. 3.

Kaźmierczak-Piwko L., Dybikowska A., Celińska E., Ratajczak J. (2017), Rola ekoznakowania produktów konsumpcyjnych w podnoszeniu świadomości ekologicznej nabywców, „Problemy w Zarządzaniu Środowiskiem” nr 7.

Komorowska D. (2009), Ekonomika produkcji ekologicznej w Polsce, „Zeszyty Naukowe SGGW. Ekonomika i Organizacja Gospodarki Żywnościowej” nr 73.

Korzycka M., Wojciechowski P. (2015), Żywność ekologiczna w prawie USA i Unii Europejskiej, „Studia Iuridica Agraria” t. XIII.

Korzycka M., Wojciechowski P. (2017), System prawa żywnościowego, Warszawa.

Korzycka-Iwanow M. (2007), Prawo żywnościowe. Zarys prawa polskiego i wspólnotowego, Warszawa.

Leśkiewicz K. (2020), Prawo żywnościowe, Warszawa.

Meulen B. van der, Velde M. van der (2008), European Food Law Handbook, Wageningen.

Muller L., Lacroix A., Ruffieux B. (2019), Environmental Labelling and Consumption Changes: A Food Choice Experiment, „Environmental and Resource Economics” Vol. 73, issue 3.

Nieżurawski L., Sobków C. (2015), Rola informacji na etykiecie w procesie zakupu produktu żywnościowego, ,Roczniki Naukowe Stowarzyszenia Ekonomistów Rolnictwa i Agrobiznesu" t. XVII, nr 3.

Olejniczak M. (2017), Zróżnicowanie źródet informacji konsumenckiej o żywności prozdrowotne, „Handel Wewnętrzny” nr 6(371).

Ozimek I. (2000), Znaczenie wybranych źródeł informacji o żywności dla konsumentów, w: K. Gutkowska, I. Ozimek (red.), Konsument żywności i jego zachowania rynkowe, Warszawa.

Ozimek I., Tomaszewska M. (2011), Znaczenie wybranych źródet informacji o produktach żywnościowych dla konsumentów, „Handel Wewnętrzny” nr 2. 
Ozimek I., Tomaszewska-Pielacha M. (2011), Czynniki wptywające na czytanie przez konsumentów informacji zamieszczanych na opakowaniach produktów żywnościowych, „Studia i Materiały Polskiego Stowarzyszenia Zarządzania Wiedzą" nr 52.

Sokołowski Ł.M. (2019), O potrzebie całościowej regulacji prawnej przeciwdziałania marnowaniu żywności, „Przegląd Prawa Rolnego” nr 1.

Staniewska K., Panfil-Kuncewicz H., Staniewski B., Mieczkowska M. (2010), Postrzeganie informacji żywieniowej przekazywanej za pomoca różnych form przekazów komercyjnych, „Zeszyty Naukowe SGGW. Ekonomika i Organizacja Gospodarki Żywnościowej” nr 86.

Wojciechowski P. (2017), Unijne prawo żywnościowe, w: M. Korzycka, P. Wojciechowski, System prawa żywnościowego, Warszawa.

Wojciechowski P. (2018), Informacja o braku zawartości określonych substancji w żywności w regulacjach prawa żywnościowego, „Przegląd Prawa Rolnego” nr 1.

Wróbel A. (red.) (2012), Traktat o funkcjonowaniu Unii Europejskiej. Komentarz, t. 2, Warszawa.

Żelazna K., Górska-Warsewicz H. (2005), Źródła informacji wykorzystywane przy zakupie żywności, w: J. Karwowski (red.), Polski konsument i przedsiębiorstwo na jednolitym europejskim rynku, Szczecin.

\title{
FOOD LABELLING AS AN INSTRUMENT FOR ACHIEVING THE OBJECTIVES OF FOOD LAW: SELECTED ISSUES
}

\begin{abstract}
Sum mary
The aim of this paper is to determine how the objectives of food law are achieved through the regulation on the labelling of food and to examine the relationship occurring between the achievement of the general objectives of food law and the particular objectives of the food labelling regulation. Having outlined the particular objectives of food law first, the author assigned to them general and detailed regulations governing the labelling of food and aimed at the achievement of particular objectives. These regulations are subsequently discussed. Their analysis leads to a conclusion that two of the objectives of food law, i.e. the protection of health and life and of consumers' interests and the reliability of trade are largely achieved by regulations shaping the obligatory scope of information that must be provided on the label. Additionally, consumer protection is ensured by labelling rules, the basic principle of which is not to mislead consumers. However, under the current legal framework, environmental and animal welfare protection is only covered to a small extent only and only by detailed regulations. Understanding consumers' expectations regarding environmental and animal welfare information, the author proposes to adopt a framework regulation that would define the rules for the use of environmental claims. Such a regulation would be similar to the regulation of nutrition and health claims.
\end{abstract}

Keywords: food law objectives, food labelling, environmental claim 


\title{
L'ETICHETTATURA DEI PRODOTTI ALIMENTARI COME STRUMENTO VOLTO A RAGGIUNGERE GLI OBIETTIVI DEL DIRITTO ALIMENTARE: ALCUNI PROBLEMI SCELTI
}

\begin{abstract}
Riassunto
L'articolo si propone di stabilire in che modo gli obiettivi del diritto alimentare vengano attuati nella regolazione riguardante l'etichettatura degli alimenti e di esaminare, a tal proposito, il rapporto intercorrente tra l'attuazione dei singoli obiettivi. L'autore parte da un abbozzo dei singoli obiettivi del diritto alimentare, per poi abbinare a essi le regolazioni, successivamente discusse, riguardanti l'etichettatura dei prodotti alimentari di carattere generale e specifico, le quali sono finalizzate a raggiungere gli obiettivi richiamati. L'analisi condotta porta alla conclusione che due degli obiettivi del diritto alimentare, ovvero la tutela della salute e della vita, nonché la tutela degli interessi dei consumatori e della correttezza commerciale, sono di prevalenza realizzati dalle disposizioni che definiscono l'ambito obbligatorio delle informazioni fornite sull'etichetta. Inoltre, la tutela dei consumatori è assicurata dalle norme in materia di etichettatura, con il principio fondamentale di non indurre in errore. La tutela dell'ambiente e del benessere animale è, invece, realizzata nell'attuale stato giuridico in misura limitata grazie a regolazioni di carattere specifico. Viste le aspettative dei consumatori in merito all'informazione ambientale e all'informazione riguardante la tutela del benessere animale, si propone di introdurre una regolazione quadro che definisca le regole per l'utilizzo delle dichiarazioni ambientali, analogamente alla regolazione in materia di indicazioni nutrizionali e sulla salute.
\end{abstract}

Parole chiave: obiettivi del diritto alimentare, etichettatura degli alimenti, dichiarazioni ambientali 